\title{
KAJIAN ANTROPOLOGI HUKUM DENGAN ILMU SOSIAL LAINNYA
}

\author{
Depi Hartato \\ depi.hartato@gmail.com \\ 2010003600005 \\ Universitas Ekasakti Padang - Fakultas Hukum
}

\section{A. PENDAHULUAN}

Antropologi sebagai disiplin ilmu terus berkembang, tidak hanya pada tataran teoritis tetapi juga sebagai ilmu terapan yang mampu memberikan masukan bagi para pembuat keputusan dalam menentukan kebijakan pembangunan. Di Indonesia, perkembangan antropologi sebagai disiplin ilmu yang dipelajari para mahasiswa di perguruan tinggi masih tergolong baru. Salah satu tokoh penting dalam perkembangan antropologi di Indonesia adalah Koentjaraningrat, sehingga dapat dikatakan bahwa ia merupakan bapak antropologi di Indonesia (Suparlan, 1988).

Sebagai disiplin ilmu, antropologi merupakan kajian yang multidisipliner yang berupaya mengkaji aspek manusia secara menyeluruh (holistik). Secara historis, antropologi berkembang dari suatu deskripsi hasil-hasil laporan perjalanan para penjelajah dan penjajah tentang kehidupan manusia di daerah yang disinggahi para penjelajah, atau kehidupan salah satu suku bangsa yang tinggal di daerah jajahan. Deskripsi tersebut dikenal dengan nama etnografi.

Dalam perjalanannya kemudian, antropologi berkembang sebagaimana keberadaannya sekarang baik di negara-negara Eropa Barat, Amerika maupun di Asia. Beberapa cabang antropologi yang dikenal secara luas saat ini adalah antropologi fisik atau biologi, antropologi sosial, dan antropologi budaya. Di sisi yang lain, antropologi juga merupakan bidang ilmu terapan sehingga hasil kajiannya dapat dimanfaatkan sebagai masukan dalam pengambilan keputusan untuk keperluan pembangunan, terutama dalam 
pembangunan sosial budaya, seperti antropologi pembangunan, antropologi kesehatan, antropologi ekonomi, dan sebagainya.

Sebagai tokoh sentral di Indonesia, Koentjaraningrat telah meletakkan dasar-dasar antropologi Indonesia. Beberapa tugas yang berhasil diembannya adalah 1) mengembangkan prasarana akademis ilmu antropologi; 2) mempersiapkan dan membina tenaga-tenaga pengajar dan tenaga ahli di bidang antropologi; dan 3) mengembangkan bahan pendidikan untuk pembelajaran bidang antropologi (Masinambow, 1997). Sebagai disiplin ilmu, antropologi merupakan kajian yang multidisipliner yang berupaya mengkaji aspek manusia secara menyeluruh (holistik). Secara historis, antropologi berkembang dari suatu deskripsi hasil-hasil laporan perjalanan para penjelajah dan penjajah tentang kehidupan manusia di daerah yang disinggahi para penjelajah, atau kehidupan salah satu suku bangsa yang tinggal di daerah jajahan.

Deskripsi tersebut dikenal dengan nama etnografi. Dalam perjalanannya kemudian, antropologi berkembang sebagaimana keberadaannya sekarang baik di negara-negara Eropa Barat, Amerika maupun di Asia. Beberapa cabang antropologi yang dikenal secara luas saat ini adalah antropologi fisik atau biologi, antropologi sosial, dan antropologi budaya. Di sisi yang lain, antropologi juga merupakan bidang ilmu terapan sehingga hasil kajiannya dapat dimanfaatkan sebagai masukan dalam pengambilan keputusan untuk keperluan pembangunan, terutama dalam pembangunan sosial budaya, seperti antropologi pembangunan, antropologi kesehatan, antropologi ekonomi, dan sebagainya.

\section{B. PEMBAHASAN}

Di dalam perkembangan antropologi, masalah hukum sebenarnya juga sudah pernah ditelaah, walaupun di dalam suatu kerangka kebudayaan yang serba luas. Sarjana-sarjana antropologi seperti Barton, Radcliffe-Brown, Malinowski dan lainnya, pernah memusatkan perhatian pada hukum sebagai suatu gejala sosial-budaya. Menurut Ihromi (1986; 3) relevansi 
menelaah hukum dari segi antropologi, antara lain adalah: (a). Berkenaan dengan masalah yang dihadapi oleh negara-negara berkembang (tentunya termasuk Indonesia) yang secara budaya bersifat pluralistis dalam cita-citanya mewujudkan unifikasi hukum atau modernisasi hokum; (b). berkenaan dengan kemungkinan munculnya masalah bila warga masyarakat dari lingkungan sukubangsa tertentu masih mempunyai norma-norma tradisional yang kuat dan menuntut ketaatan mengenai hal-hal tertentu, sedangkan dalam norma hukum yang sudah tertulis dan berlaku secara nasional, hal- hal yang harus ditaati itu justru dirumuskan sebagai hal yang terlarang.

Secara faktual, masalah-masalah yang dirumuskan ke dalam dua point utama itu sudah terjadi, baik berkenaan dengan munculnya konflik horisontal di pelbagai wilayah, pertikaian antara state (maupun pemda) dengan masyarakat, maupun antar kelompok masyarakat sendiri. Hukum, menurut Benda-Beckmann $(1979 ; 113-114)$ adalah suatu cara khusus untuk membatasi otonomi anggota-anggota masyarakat. Kebanyakan penulis menyetujui bahwa hukum adalah suatu bentuk pengawasan sosial, itulah mengapa secara esensial sifatnya normatif, dan hal itu merujuk pada apa yang disebut (sebagai) konsepsikonsepsi yang obyektif.

Implikasi pendekatan semacam ini adalah: bahwa hukum memberi input kepada pranata pengendalian sosial (apapun variant-nya) dan kemudian kepada rujukan berpikir masyarakat, dan sebaliknya. Hukum, di sisi lain, dapat pula menyebabkan perubahan perangkat berpikir, dan rujukan kemasyarakatan lainnya atau dikenal dalam sosiologi hukum sebagai "law as tool of social engineering". Namun, bila kesemua hal itu berubah (dan pada kenyataannya memang selalu demikian), maka hukum pun berubah mengikuti perubahan masyarakat dan lingkungannya. 
Dibawah ini dapat kita pahami keterkaitan antara Antropologi dengan beberapa bidang ilmu lainnya, seperti dengan ilmu administrasi, Ilmu Politik, Ilmu Sejarah, dan sebagainya.

\section{Hubungan Antropologi dan Sosiologi}

Hubungan antara Antropologi dan sosiologi pada satu sisi, memperlihatkan bahwa sebagian para ahli tidak lagi membedakan kedua ilmu tersebut secara ketat. Artinya beberapa fokus kajiannya dianggap sama bahkan beberapa paradigma yang digunakan untuk melihat suatu fenomena sosial pun dianggap tidak memiliki perbedaan. Kedua ilmu itu bisa saling menukar atau saling melengkapi baik menyangkut paradigma ataupun metode yang digunakan dalam mengungkap suatu fenomena sosial.

Di pihak ini, perbedaan antropologi dan sosiologi hanya terjadi pada sejarah berdirinya masing-masing ilmu tersebut. Namun dalam perkembangan selanjutnya, kedua ilmu itu dapat saling melengkapi bahkan melebur diri menjadi satu ilmu. Pada universitas tertentu, antropologi dan sosiologi merupakan program studi yang dikembangkan secara bersama-sama di bawah departemen antropologi-sosiologi atau sosiologi-antropologi. Benarkah antropologi dan sosiologi sudah tidak dapat dibedakan lagi?

Ada pihak lain yang masih tetap mempertahankan adanya perbedaan antara antropologi dan sosiologi. Secara historis, kemunculan kedua ilmu tersebut adalah berbeda baik dari segi paradigma yang digunakan, metode yang digunakan atau pun sasaran masyarakat yang menjadi obyek penelitiannya. Di mana antropologi menekankan kajiannya pada masyarakat tradisional di luar masyarakat Barat, sedangkan sosiologi lebih menekankan pada masyarakat perkotaan yang pada saat itu ada pada masyarakat Barat sendiri.

Dalam perkembangannya, menurut pihak ini, masih dapat dilihat adanya perbedaan di antara kedua ilmu tersebut. Walaupun menurut penulis, perbedaan ini lebih didasari oleh selera dalam menggunakan paradigma dan metode yang digunakan. Sedangkan sasaran 
penelitiannya, sering kali tidak dapat lagi dibedakan karena keduanya sama-sama memperhatikan fenomena sosial di pedesaan (masyarakat tradisional) ataupun di perkotaan (masyarakat industri).

\section{Hubungan Antropologi dan Ilmu Politik}

Perkembangan ilmu terus berlanjut, begitu pula dengan ilmu politik, yang mulai banyak menaruh perhatian terhadap berbagai fenomena budaya masyarakat yang terkait langsung atau tidak langsung. Keanggotaan partai politik di Indonesia sangat dipengaruhi oleh kondisi budaya masyarakatnya. Budaya masyarakat di Indonesia yang cenderung patrimonial sangat berpengaruh pada sistem budaya politiknya. Untuk itu, untuk lebih dapat memahami perilaku politik masyarakat di Indonesia, Anda perlu belajar tentang kebudayaan masyarakat di Indonesia, yang terdiri dari bermacam- macam suku bangsa dan masingmasing suku bangsa tersebut memiliki kebudayaannya yang khas. Untuk keperluan tersebut, antropologi mempunyai peran dalam kaitannya dengan kajian ilmu politik, karena mampu mengungkap kebudayaan suatu masyarakat yang akan menjadi tempat bagi perilaku politik.

\section{Hubungan Antropologi dan Ilmu Ekonomi}

Ilmu Ekonomi yang mengkaji fenomena ekonomi modern lebih didasari oleh pemikiran-pemikiran Barat atau Ero-Eropa. Persoalannya adalah bilamana pemikiranpemikiran ekonomi diterapkan pada setiap masyarakat terutama masyarakat yang masih sederhana atau negara terutama negara- negara berkembang tidak selamanya akan sesuai karena dilatarbelakangi oleh faktor cara pandang yang berbeda pada kehidupan ekonominya. Perhitungan ekonomi modern tidak selamanya dapat diterapkan pada sistem ekonomi masyarakat non Barat.

Keragaman budaya pada setiap masyarakat atau suku bangsa memperlihatkan pula adanya keragaman dalam strategi kehidupan ekonominya. Keragaman pada sistem ekonomi dapat dilihat pada sistem produksi apakah bercocok tanam sebagai petani, nelayan, 
peternakan, dan sebagainya. Begitu pula keragaman ini dapat dilihat pada sistem tukar menukar atau sistem jual beli barang.

Pada kondisi seperti di atas, antropologi sangat diharapkan perannya untuk dapat menjembatani pemikiran ekonomi modern dan pemikiran ekonomi lokal. Pembangunan ekonomi masyarakat di negara-negara berkembang tidak akan berjalan dengan baik bilamana tanpa diikuti oleh pertimbangan aspek budaya lokal terutama yang terkait dengan pola pikir kehidupan ekonominya. Terdapat perbedaan pandangan, anggapan, pengetahuan, persepsi pada masyarakat industri dengan masyarakat nonindustri seperti pertanian. Oleh karena itu perlu kehati-hatian para perencana pembangunan yang mencoba mengadopsi pemikiran atau teknologi yang datang dari masyarakat industri (negara-negara Barat) bagi kepentingan untuk meningkatkan kesejahteraan masyarakat nonindustri.

\section{Hubungan Antropologi dan Ilmu Administrasi}

Pentingnya antropologi bagi Ilmu Administrasi adalah terkait dengan kebutuhan Ilmu Administrasi untuk memecahkan persoalan-persoalan administrasi pemerintahan. Kondisi sistem administrasi pemerintahan yang dianggap masih kurang baik oleh sebagian pihak, seperti masalah pemilikan tanah, membutuhkan pemecahan bukan saja dari pihak pegawai atau para admonistartur tetapi juga karena aspek yang bersumber pada latar belakang sosial budaya masyarakat yang belum menganggap penting masalah administrasi.

\section{Hubungan Antropologi dan Arkeologi serta Ilmu Sejarah}

Pada dasarnya arkeologi bertujuan menyingkap sejarah kebudayaan manusia dari mulai kebudayaan kuno pada jaman purba seperti kebudayaan Mesopotamia dan kebudayaan Mesir Kuno. Di Indonesia, Arkeologi memfokuskan perhatiannya kepada kebudayaan di Indonesia pada masa Hindu yang hidup sekitar abad ke 4 hingga abad ke 16. Hasil penelitian arkeologi terhadap bahan bekas reruntuhan atau alat-alat peninggalan kerajaan Hindu di 
Indonesia adalah sebuah deskripsi sejarah manusia yang kemudian dapat digunakan oleh antropologi sebagai bahan untuk merekonstruksi sejarah asal-mula makhluk manusia.

Dilihat dari batasan kajiannya, antropologi terlihat lebih luas karena tidak hanya memfokuskan pada benda-benda peninggalan (artifak) saja, melainkan juga pada sistem ide (gagasan dan sistem tingkah laku). Kesulitan di dalam merekonstruksi kembali kehidupan dan persebaran kebudayaan, antropologi dan ilmu sejarah saling bertukar metode dan teori untuk lebih dapat memahami masyarakat pada umumnya. Begitu pula penggambaran tentang hasil penelitian keduanya bisa saling melengkapi sesuai bagi tujuan tertentu.

\section{PENUTUP}

Sosiologi hukum dan antropologi hukum memiliki objek yang jelas yaitu manusia. Antropologi hukum mengkaji suatu budaya yang terjadi pada kelompok masyarakat dan sosiologi hukum lebih menitik beratkan pada pada manusia dan berbagai proses hubungan sosialnya. Adanya antropologi hukum dan sosiologi hukum membuat kehidupan masyarakat

menjadi lebih teratur. Berbagai bentuk penyimpangan sosial memang kerap kali terjadi di lingkungan masyarakat, namun ada banyak langkah pencegahan yang bisa dilakukan dan salah satunya dengan mempelajari ilmu sosiologi hukum serta ilmu antropologi hukum.

Telaah akan hasil kreasi, distribusi dan transmisi Pengkajian Antropologi Hukum telah memberikan hukum yang ada. Kajian mengenai bagaimana kekuasaan hukum berproses dan memberi dampak dalam masing-masing masyarakat. Selanjutnya akan menampilkan bagaimana feed back dan pengaruh masyarakat-masyarakat terhadap kekuasaan hukum tersebut. Kemajemukan hukum yang ada di Indonesia dewasa ini merupakan soal tersendiri mengingat otetisitas Antropologi Hukum yang sejak lama menempatkan dan menghargai the other laws secara proporsional dan kontekstual. Dengan demikian para pengkaji antropologi hukum ditantang untuk memberikan kontribusi bagi perkembangan hukum di Indonesia. 


\section{DAFTAR PUSTAKA}

Gokma Toni Parlindungan S, Asas Nebis In Idem Dalam Putusan Hakim Dalam Perkara Poligami Di Pengadilan Negeri Pasaman Sebagai Ceriminan Ius Constitutum, Volume 2, Nomor 1, 2020.

Gokma Toni Parlindungan S, Pengisian Jabatan Perangkat Nagari Pemekaran Di Pasaman Barat Dalam Rangka Pelaksanaan Otonomi Daerah, Ensiklopedia Of Journal, Vol 1 No 2 Edisi 2 Januari 2019.

Harniwati, Peralihan Hak Ulayat Menurut Undang-Undang Nomor 18 Tahun 2004, Volume 1, Nomor 3, 2019.

Jasmir, Pengembalian Status Hukum Tanah Ulayat Atas Hak Guna Usaha, Soumatera Law Review, Volume 1, Nomor 1, 2018.

Jumrawarsi Jumrawarsi, Neviyarni Suhaili, Peran Seorang Guru Dalam Menciptakan Lingkungan Belajar Yang Kondusif, Ensikopedia Education Review, Vol 2, No 3 (2020): Volume 2 No.3 Desember 2020.

Mia Siratni, Proses Perkawinan Menurut Hukum Adatdi Kepulauan Mentawai Di Sebelum Dan Sesudah Berlakunya Undang-Undang Nomor 1 Tahun 1974 Tentang Perkawinan, Ensiklopedia Of Journal, Vol 1 No 2 Edisi 2 Januari 2019,

Remincel, Dimensi Hukum Pelanggaran Kecelakaan Lalu Dan Angkutan Jalan Lintas Di Indonesia, Ensiklopedia Social Review, Volume 1, Nomor 2, 2019.

R Amin, B Nurdin, Konflik Perwakafan Tanah Muhammadiyah di Nagari Singkarak Kabupaten Solok Indonesia 2015-2019, Soumatera Law Review, Volume 3, Nomor 1, 2020. 